\title{
Equivalency Education through Homeschooling: a Constructive Collaboration in Non-Formal and Informal Education in Indonesia
}

\author{
Tintin Kartini \\ Student of Curriculum Development, School of Postgraduate Studies \\ Universitas Pendidikan Indonesia (UPI) \\ Bandung, Indonesia \\ tintinjayagiri@gmail.com
}

\begin{abstract}
Equivalency education is non-formal education carried out for those who cannot access formal primary and secondary education. It is carried out in some diversification services, one of which is through homeschooling. This study aims to explore how equivalency education applied through homeschooling. The study employed a qualitative research approach which utilized exploratory method. Interview and observation were used to collect the required information carried out to homeschooling institution, families of homeschoolers, and CLCs. The collected data were analyzed using content analysis. The findings are (1) homeschooler generally has a strong consideration to choose homeschooling (2) homeschoolers have different strategy and methods in which emphasis more on the optimization of talents, interests and aspirations of learners, (3) learning resources are designed to meet the learning style, time, and facilities; and (4) the progress of learners is evaluated directly by the parents and/or by the "umbrella school". Therefore, the collaboration between nonformal institutions such as Community Learning Centers and Homeschooling institutions with homeschooler families as informal "institution" in carrying out equivalency education is highly needed especially for quality assurance of learning process and evaluation.
\end{abstract}

Keywords-equivalency education, homeschooling, non-formal education, informal educatino, learning

\section{INTRODUCTION}

Equivalency education is a non-formal education program equivalent to formal primary and secondary school. It consists of Package A equivalent to elementary school, Package B equivalent to junior high school, and Package $\mathrm{C}$ equivalent to senior high school [1]. Equivalency education services become an urgent need in Indonesia. It is not only because such factor as drop-out from formal schools, economy, geography, and beliefs, but also because of the development of science, technology, communication and learning needs with the demands of new ways. One form of new ways in equivalency education is homeschooling.

Homeschooling system develops so rapidly. As reported in Kompas, 16 March 2015, member of AsahPena, an association for homeschoolers and alternative education practitioners, were about 5,000 registered in 2012 from all over Indonesia and become about 11,000 members in 2013, and about 30,000 in
2014. However, the numbers are of registered in AsahPena only and it may be an" iceberg" phenomenon; the actual number could be much more because many other homeschoolers do not register in any associations or communities.

However, there rise doubts about the existence of homeschooling; how is the learning process carried out; how are the learners' competences assessed; most of all is do the learning process enable the learner to master the competences as other learners participated in equivalency education units such as in the CLC, learning groups, courses and another nonformal education unit.

Regarding to this reasoning, it is needed to conduct an exploratory study of how equivalency education applied through homeschooling

\section{LITERATURE REVIEW}

\section{A. Formal, Non-Formal, and Informal Education}

Formal education corresponds to a systematic, organized education model, structured and administered according to a given set of laws and norm, presenting a rather rigid curriculum as regards objectives, content and methodology. In other words, formal education has a well-defined set of components.

If some of the components are absent, the system has shifted to more non-formal system. The absence could be not requiring the student attendance, decreasing contact between teacher and students, or most activities take place outside the institution. Non-formal education programs are organized for learning, coming to complement, support or as a source of valorization of the learning experiences formally acquired. Examples of non-formal programs are libraries, music course, foreign language course, dance, theatre, sports, painting, mimicry etc.

Informal education does not correspond to an organized and systematic features; it does or necessarily include the objectives and subjects usually encompassed by the traditional curricula. The learners often do the learning unintentionally. [2][3]. 


\section{B. Equivalency Education}

Equivalency Program is a non-formal education program that includes Package A equivalent to elementary school, Package B equivalent to junior high school, and Package $\mathrm{C}$ equivalent to senior high school with an emphasis on the acquisition of knowledge, functional skills as well as developing a professional attitude and personality of the learners. Equivalency Program emphasis on applicable concept, thematic, inductive, and directly related to environmental issues around students, integrated with life skills-oriented process as preparation for employment and entrepreneurship. Specifically, graduates of Package A is expected to have the basic skills to meet daily needs; graduates of Package B are having the skills to meet the demands of employment; and graduates of Package $\mathrm{C}$ has the skills for entrepreneurship [4]

\section{Homeschooling}

The term "homeschooling" refers to education activity in which parents teach their children at home. Compared with school-based education, homeschooling and school-based education can be seen as two extremes in a continuum. In some case, children would be taught in part by their parents and in part at school; it can be seen as intermediate form [5].

However, long before school existed, parents, or those pointed, taught their children to fulfill their needs. Throughout recorded history, parents or guardians have taught their own children [6]. Even until this digital era, still homeschooling becomes interesting choice for some families.

In the context of Indonesia, homeschooling belongs to the informal education and equivalency education to non-formal education. However, as Zaki stated that the higher the degree of systematization and organization involved in informal education activities, the nearer it will be to non-formal education [2].

\section{RESEARCH METHOD}

The study employed qualitative research approach which utilized exploratory method by literature reviewing, interview, and observation. Literature reviewing was conducted to explore concept, application, and regulation of equivalency education as well as homeschooling. References were from journal, article, regulations, reports and other relevant sources. The reasoning and experiences of homeschoolers were also explored by reviewing some compilation writings of homeschoolers.

The reasoning and experiences were also explored through interview with sample of parents, learners, tutors, and association of homeschoolers. The interviews were performed in homeschoolers gathering, compound learning process.

How the content standards of equivalency education were applied in homeschooling was analyzed based on the observation of learning process and its documents.

\section{RESULT AND DISCUSSION}

The finding is: first, the learners and parents of homeschooling generally have a strong consideration to choose homeschooling as an alternative to education. The reasons of choosing homeschooling among others are parents' idealism, children having special activities such artists, athletes, beliefs, highly-mobile families, children having special conditions such as super genius, slow learner, disabilities, or for some reason having no access to formal schools [7].

Second finding is that compared with those held by other education units, learners and parents of homeschooling have different strategy and methods in which emphasis more on the optimization of talents, interests and aspirations of learners, both with regard to academic subjects and non-academic [8]. For example, parents or a group of parents designed a project to be done by the children; the projects themselves were designed in such a way that children learn some competences from some different subjects. Parents also arranged field trip, field visit or gathering with another homeschooler. Generally, children were given the opportunity to determine their own schedule under the guidance of parents. Some parents also hired tutor(s) to assist them in teaching their children; some other collaborated with education unit such as Community Learning Centre or Community Homeschooling in carrying out their children education

The third is that learning resources were designed to meet the learning style, time, and facilities. Parents used variety of learning resources such as the Internet-based teaching materials, audio-video material, books and other references resources tailored to the characteristics of children. Some parents used online learning sites; some other used material designed in collaboration with CLC or community homeschooling.

The last finding is that the progress of learners is evaluated directly by the parents and/or by the "umbrella school". The umbrella schools could be CLC or community homeschooling. Although families are responsible with the learning process as well as evaluation, but the recognition toward the evaluation need to be carried out. The evaluation was based on the standard of equivalency education.

The conclusion of research is that equivalency education through homeschooling academically accountable. Community Learning Centers adn Homeschooling Institutions play an important role both in assuring learning process and evaluation.

Recommendations of the research are 1) policy umbrella for the existence of homeschooling, and 2) final examination that is different and independent, but is recognized equivalent to formal education in the same level 3) evaluation institution(s) that assess learners' competence and/or to recognize the assessment result carried out by parents.

\section{REFERENCES}

[1] Act of Republic of Indonesia Number 20, Year 2003 on National Education System 
[2] Zaki, Claudio, "Formal, Non-Formal, and Informal Education:Concept/Applicability", Interamerican Conference on Physics Educatio, 300-315, 1988.

[3] Tudor, Sofia Loredana, "Formal-Non-Formal-Informal in Education", 5th International Conference EDU-WORLD 2012-Education Facing Contemporary World, 821-826.2012

[4] The Decree of Indonesia Ministry of Education Number 14, Year 2007 on Standard of Content of Equivalency Education

[5] Block, H, "Performance in Home Schooling: An Argument against Compulsory Schooling in the Netherlands", International Review of Education, 50(1), 39-52, 2004
[6] Petrie, A. J. "Home educators and the law within Europe" International Review of Education, 41(3-4), 285-296, 1995.

[7] Maria Van Tiel, Dkk, Antologi Anak Gifted. Jakarta: Gramedia Widiasarana Indonesia.2014

[8] Mulyadi, Seto, "Student's Tutorial System perception, Academic SelfEfficacy, and Creativity Effects on Self-Regulated Learning", Future Academy's Multidiciplinary Conference, 598-602, 2016. 